\title{
Zmiany w zakresie ochrony obligatariuszy oraz obowiązków emitentów obligacji
}

\section{The amendments in bond-holders' protection and bond issuers'obligations}

\author{
dr hab. Tomasz Sójka
}

E-mail: tsojka@amu.edu.pl;nr ORCID: 0000-0001-7555-6829

\section{mgr Adrian Rycerski}

E-mail: adrryc@amu.edu.pl; nr ORCID: 0000-0002-4673-0450

\begin{abstract}
Streszczenie
Artykuł prezentuje wybrane zmiany w ustawie z 15.01.2015 r. o obligacjach dokonane na mocy ustawy z 9.11.2018 r. o zmianie niektórych ustaw w związku ze wzmocnieniem nadzoru nad rynkiem finansowym oraz ochrony inwestorów na tym rynku. Analizę tę zasadniczo ograniczono do dwóch aspektów, a mianowicie obligatoryjnej dematerializacji ob- ligacji oraz obowiązku uczestnictwa agenta emisji w procesie emisji tych instrumentów finansowych. Oceniono wpływ nowych przepisów na zakres ochrony inwestorów oraz koszty pozyskiwania finansowania dłużnego. Odniesiono się tak- że do najważniejszych instytucji wdrożonych do krajowego porządku prawnego na mocy dyrektywy 2014/65/UE oraz wynikających z rozpoczęcia stosowania rozporządzenia 2017/565, co było niezbędne przy dokonywaniu oceny nowych środków prawnych tworzonych z inicjatywy prawodawcy krajowego.
\end{abstract}

Słowa kluczowe: emitent, obligacja, instrument finansowy, ochrona inwestorów

\section{Summary}

This article demonstrate selected amendments in the Act on bonds of 15th January 2015 carried outin the Act on the amendment of selected acts in conjunction with the strengthening of market surveillance and investor's protection on the financial market of 9th November 2018. The analysis has been limited to two aspects, specifically to the obligatory bonds' dematerialization and the duty to sign an agreement with the agent in process of the bond issuance. The impact of the new regulation on scope of investors' protection and the costs of debt financing have been assessed. The subject of this article is also to demonstrate the main legal measures which have been implementedunder the directive 2014/65/UE and which have been applied under the regulation 2017/565. The assessment of the aforementioned measures was necessary in order to analyse the new ones.

Key words: issuer, bond, financial instrument, investor's protection

JEL: G21

Str. 2-8

\section{Bibliografia}

\section{Literatura}

Bączyk, M., Jakubiec, A., Katner, P., Romanowski, M. (2018). Umowy o doradztwo inwestycyjne. W: W. J. Katner (red.). System Prawa Prywatnego (t. 9). Prawo zobowiąań - umowy nienazwane. Warszawa: C.H. Beck.

Cichorska, J. (2017). Misselling, czyli sprzedaż niepotrzebnych instrumentów finansowych i jej skutki. Stan prawny w Polsce i Wielkiej Brytanii. Journal of Insurance, Financial Markets \& Consumer Protection, 24(2), 18-34.

Dziennik-Marciniak, K., Rycerski, A. (2018). Regulacja MiFID II i jej wpływ na działalność podmiotów z sektora energetycznego. Rynek Energii, (1), 79-86. 
Dybiński, J. (2016). Ochrona klienta na rynku usług inwestycyjnych. W: M. Stec (red.), System Prawa Handlowego (t. 4). Prawo instrumentów finansowych. Warszawa: C.H. Beck.

Frunza, M. Ch. (2015). Introduction to the theories and varieties of modern crime in financial markets. Amsterdam-Boston: Elsevier.

Ganczar, M. (2016). Misselling - nowa praktyka naruszająca zbiorowe interesy konsumentów w świetle nowelizacji ustawy o ochronie konkurencji i konsumentów z 2015 r. W: M. Czarnecka (red.), T. Skoczny (red.), Prawo konsumenckie w praktyce. Warszawa: C.H. Beck.

McMeel, G., Virgo, J. (2001). Financial Advice and Financial Products. Law and liability. Oxford: Oxford University Press.

Sójka, T. (2018). Uprawnienia organizacyjne obligatariuszy. Studium cywilnoprawne ze szczególnym uwzględnieniem pozasądowej restrukturyzacji zobowiązań zobligacji. Warszawa: C.H. Beck.

Sójka, T. (2016). Obowiązek lojalności usługodawcy: powierniczy charakter umów o świadczenie usług maklerskich. W: T. Sójka (red.). Cywilnoprawna ochrona inwestorów korzystajacych z usług maklerskich na rynku kapitałowym. Warszawa: Wolters Kluwer Polska.

Uzasadnienie (2018). Uzasadnienie do rządowego projektu ustawy o zmianie niektórych ustaw w zwiazku ze wzmocnieniem nadzoru oraz ochrony inwestorów na rynku finansowym (Sejm VIII kadencji, druk $\mathrm{nr}$ 2812). http://www.sejm.gov.pl/sejm8. nsf/druk.xsp?nr=2812 (30.04.2019).

\section{Akty prawne}

Dyrektywa Parlamentu Europejskiego i Rady 2014/65/UE z 15.05.2014 r. w sprawie rynków instrumentów finansowych oraz zmieniająca dy- rektywę 2002/92/WE i dyrektywę 2011/61/UE (Dz. Urz. UE L 173, s. 349, ze zm.) - dyrektywa 2014/65/UE.

Dyrektywa delegowana Komisji (UE) 2017/593 z 7.04.2016 r. uzupełniająca dyrektywę Parlamentu Europejskiego i Rady 2014/65/UE w od- niesieniu do zabezpieczenia instrumentów finansowych i środków pieniężnych należących do klientów, zobowiązań w zakresie zarządzania produktami oraz zasad mających zastosowanie do oferowania lub przyjmowania wynagrodzeń, prowizji bądź innych korzyści pieniężnych lub niepieniężnych (Dz. Urz. UE L 87 z 2017 r., s. 500) — dyrektywa delegowana.

Rozporządzenie delegowane Komisji (UE) 2017/565 z 25.04.2016 r. uzupełniające dyrektywę Parlamentu Europejskiego i Rady 2014/65/UE w odniesieniu do wymogów organizacyjnych i warunków prowadzenia działalności przez firmy inwestycyjne oraz pojęć zdefiniowanych na potrzeby tej dyrektywy (Dz. Urz. UE L 87, s. 1, ze zm.) - rozporządzenie 2017/565.

Ustawa z 29.07.2005 r. o obrocie instrumentami finansowymi (Dz. U. z 2018 r. poz. 2286 ze zm.) - u.o.i.f.

Ustawa z 16.02.2007 r. o ochronie konkurencji i konsumentów (Dz. U. z 2019 r. poz. 369).

Ustawa z 15.01.2015 r. o obligacjach (Dz. U. z 2018 r. poz. 483 ze zm.) - u.o.

Ustawa z 1.03.2018 r. o zmianie ustawy o obrocie instrumentami finansowymi oraz niektórych innych ustaw (Dz. U. poz. 685).

Ustawa z 9.11.2018 r. o zmianie niektórych ustaw w związku ze wzmocnieniem nadzoru nad rynkiem finansowych oraz ochrony inwestorów na tym rynku (Dz. U. poz. 2243) — nowelizacja z 9.11.2018 r..

Rozporządzenie Ministra Finansów z 30.05.2018 r. w sprawie trybu i warunków postępowania firm inwestycyjnych, banków, o których mowa w art. 70 ust. 2 ustawy o obrocie instrumentami finansowymi, oraz banków powierniczych (Dz. U. poz. 1112) - rozporządzenie MF. 